\title{
Seed Oil Content and Fatty Acids Composition of Maize under Heat and Water Stress
}

\author{
A. Ashgan Abou Gabal ${ }^{1}$ and F. Amera Zaitoun ${ }^{1 *}$
}

\begin{abstract}
Water deficiency and high temperature has adverse effect on the economic importance of maize crop. A field experiment was conducted during summer 2012 to assess the variation in oil content and fatty acids synthesis with respect to drought and heat tolerance in eight maize genotypes at a farm in El-Omaid village, El Hamam city, Marsa Matroh government. Relative water content (RWC) and cell membrane thermos-stability (CMT) were measured and oil content and fatty acids composition were also estimated. Water deficit and heat caused a significant reduction in RWC of all genotypes studied in contrary to cell membrane injury which was elevated significantly due to stresses. Analysis of maize seeds showed that the oil content decreased significantly. It was found that genotypes have significant effect on oleic, linoleic and arachidic acids, while water stress affected significantly on palmitic, oleic, linoleic, arachidic and homo-gammalinolenic acids. Furthermore, the interaction between genotypes and water stress had a significant effect on both oleic and linoleic. On the other hand, there were an increasing in both ratios of unsaturated/saturated fatty acids (average increased from 3.15 to 3.86 ) and oleic/Stearic (average increased from 4.89 to 7.73 ) revealed that unsaturation of fatty acids increased under both stresses. The results indicated that genotype DT62 and DT190 have oil composition less affected under drought and heat stress and it's recommended to be used in the maize improvement programmers in Egypt.
\end{abstract}

\section{INTRODUCTION}

Maize (Zea mays L.) is the third most important cereals after wheat and rice all over the world as well as in Egypt. It is the major cereal grain used for the commercial production of vegetable oil. The parts of corn kernels are endosperm $(82 \%)$, germ (embryo and scutellum) (12\%). 80 to $84 \%$ of total kernel oil is present in the germ region followed by $12 \%$ in aleurone and 5\% in endosperm (Watson et al., 2003). The amount of germ in the kernel and oil in the germ is genetically controlled and vary widely (Becker, 2007). The typical maize kernel, on dry weight basis is composed from $61-78 \%$ of starch, $6-12 \%$ of proteins, $3.1-5.7 \%$ of oil, $1.0-3.0 \%$ of sugar and $1.1-3.9 \%$ of ash (Watson et al., 2003).

The typical fatty acids profile of a maize kernel contains $57.9 \%$ of linoleic acid, $<1 \%$ of linolenic acid, $25.2 \%$ of oleic acid, $11.6 \%$ of palmitic acid and $1.8 \%$ of stearic acid (White et al., 2003). Concerning to fatty acids in maize oil, the unsaturated fatty acid is composed of about $80 \%$ of linoleic acid which is an indispensable fatty acid. It has the efficiency to reduce cholesterol content, soften blood vessels, enhance the function of cardiovascular system, prevent and improve the arteriosclerosis (EFSA Panel on Dietetic Products, Nutrition and Allergies, 2011).

It is well known that genetic and environmental factors play an important role in the economic importance of a crop and can affect the oil yield and quality of its seed/grain production (Triboi and TriboiBlondel, 2002). In addition, the combination of drought and heat stress was found to alter physiological processes such as photosynthesis, accumulation of lipids, and transcript expression (Jiang and Huang, 2001; Rizhsky et al., 2004). Some earlier studies have shown that quality of seed composition depends on the type of cultivar, amount of irrigation used for production (Bellaloui and Mengistu, 2008) and period taken to full maturity of cultivars (Zhang et al., 2006). It has been documented that the ratio of oleic /linoleic acid increases under high temperature during seed maturation and, in opposition, it decreases under lower temperature conditions. At elevated temperatures, with high night temperatures, a marked reduction in the percentage of linoleic acid occurs, apparently due to desaturase enzymes that are essential for the conversion of oleic to linoleic acid. It is now well recognized that reduced yields and altered oil composition occur in sunflower crop that matures under high temperature conditions. Whole ranges of metabolic changes that occur due to abnormal temperature cycle adversely affect the biosynthesis of fatty acids in sunflower (Nagarajan and Nagarajan, 2010).

The relative water content (RWC) stated by Slatyer in 1967 is a useful indicator of the state of water balance of a plant essentially because it expresses the absolute amount of water, which the plant requires to reach artificial full saturation. Thus there are a relationship between RWC and water potential (González et al., 2001). It is defined that decrease of relative water content close stomata and also after blocking of stomata will reduce photosynthesis rate (Cornic, 2000). It is reported that high relative water

\footnotetext{
${ }^{1}$ Department of Botany, Faculty of Agriculture, Alexandria, Egypt

*Corresponding author email: gene.expression83@yahoo.com

Received September 13, 2015, Accepted September 28,2015
} 
content is a resistant mechanism to drought, and that high relative water content is the result of more osmotic regulation or less elasticity of tissue cell wall (Ritchie et al., 1990). The difference of relative water content (RWC) has been reported in durum wheat as 18.6 and 21.8 percent for most resistant and most sensitive genotypes to drought stress in 2 years of experiment. (Merah, 2001). In studies that performed on 4 cultivars of bread wheat, RWC reduced to 43 percent (from $88 \%$ to $45 \%$ ) by moisture stress (Siddique et al., 2000).

The cell membrane thermostability (CMT) assay is an indirect screening technique for heat tolerance and also provides a reliable measure of tissue tolerance to heat and drought stress. The CMT assay has been successfully used to identify heat tolerant and susceptible genotypes in several crop species among of them cereal crops (Tripathy et al., 2000 and Jamal et al., 2014). Under high temperatures, peroxidation of unsaturated fatty acids in membrane lipids is responsible for cell membrane damage (Cui et al., 2006 and Gomathi and Rakkiyapan, 2011). Results of Kebede et al. (2012) study showed that heat stress significantly decreased CMT in the corn plants, suggesting that damage to the cell membranes may have been caused by lipid peroxidation.

There is a very little work has been reported about the effect of drought stress on maize kernel oil composition in different Inbred Lines of maize. So, The present work aims at determining the effects of drought stress on physiological processes and seed oil content and fatty acids composition.

\section{MATERIALS AND METHODS}

A field experiment was conducted during summer 2012 to assess the variation in oil content and fatty acids synthesis with respect to drought tolerance in maize genotypes at a farm in El-Omaid village, El Hamam city, Marsa Matroh government. The soil of experimental site was loamy sand. The hottest day of 2012 was May 22, with a high temperature of $40^{\circ} \mathrm{C}$. The hottest month of 2012 was August with an average daily high temperature of $32^{\circ} \mathrm{C}$. The longest warm spell was from June 9 to August 31, constituting 84 consecutive days with warmer than average high temperatures. The field experiment was laid out in a randomized completely block design with 8 genotypes; DT235, DT62, DT190, DT79, DT196, DT61 obtained from International Maize and Wheat Improvement Center (CIMMYT) and INB176 and INB209 obtained from Field Crops Research Institute, Agriculture Research Center, Giza, Egypt and two irrigation treatments with three replications. Treatments details (water stress) used for present study are control with normal irrigation period 2 hours per 2 days $(75 \%$ field capacity) and stressed 1 hour per 2 days (50\% field capacity) at the critical point of growth from 45 to 70 days after sowing (DAS).

\section{Relative Water Content (RWC)}

The procedure of measuring Relative Water Content (RWC) was carried out as described by Siddique et al., (2000). Relative Water Content was measured using flag leaves after imposing drought condition (60 DAS). RWC was calculated from the equation of:

\section{Relative water content $=\frac{\text { Fresh weight }- \text { Dry weight }}{\text { Turgid weight }- \text { Dry weight }}, 100$ \\ Cell Membrane Thermo-Stability (CMT)}

Cell membrane thermo-stability was estimated following the method purposed by Ibrahim and Quick (2001). Membrane thermo-stability was expressed in percentage units as the reciprocal of relative leakage:

$\mathrm{CMT}=(1-\mathrm{T} 1 / \mathrm{T} 2) \times 100$

$\%$ Injury $=100-\mathrm{CMT}$

Where $\mathrm{T} 1$ is the conductivity reading after heat treatment and $\mathrm{T} 2$ is the conductivity reading after autoclaving.

\section{Lipid content}

Crude fat was determined according to Folch method (Folch, 1957). 1 gm of immature grains 20 days after pollination (DAP) was weighed and used for this purpose. The percentage of the crude fat was calculated using the following equation:

$\%$ crude fat $=\frac{w 2-w 1}{w s} * 100$

Where:

$\mathrm{W} 1=$ Weight of the empty flask

$\mathrm{W} 2$ = Weight of the flask + the sample after the evaporation

Ws $=$ Weight of the dried sample

\section{Oil Fatty Acids Composition}

A Hewlett - Packard 5890 gas - chromatography was used complied with a Hewlett - Packard 5989 quadropole mass spectrometer with electron ionization mode [EI] generated at $70 \mathrm{eV}$. The ion source and quadropole temperature were $230^{\circ} \mathrm{C}$ and $150^{\circ} \mathrm{C}$, respectively, and the filament emission current was 11 LA. Fatty acids were separated on HPS (5\% diphenyl, 95\% diethyl poly siloxane JWX scientific, Folsom, CA) and Fused silica capillary column $(30 \mathrm{~m} * 0.25 \mathrm{~mm}$ i.d. $* 0.25 \mu \mathrm{m}$ film). The oven temperature was increased from $70^{\circ} \mathrm{C}$ at a rate of $2^{\circ} \mathrm{C} / \mathrm{min}$ up to $220^{\circ} \mathrm{C}$ where it was held for 30 minutes. The on - column injector was heated from $20^{\circ} \mathrm{C}$ to $245^{\circ} \mathrm{C}$ and $180^{\circ} \mathrm{C}$, the detector temperature was $245^{\circ} \mathrm{C}$. Helium was the carrier gas 1.1 
$\mathrm{ml} / \mathrm{min}$. Electron impact mono spectra were recorded in the $40-600$ amu range at $15 /$ interval. Injected volumes were $1 \mu \mathrm{l}$ of concentrated extract. Compounds were identified on the basis of linear relation indices on the column and EI mass spectra from the literature. The amount of resulted fatty acids was expressed as $\mu \mathrm{g} n$ hexanol equivalent/g of fresh weight.

\section{RESULTS AND DISCUSSION}

\section{Relative Water Content (RWC)}

The results of the mean squares for Relative water content (RWC) character presented in Table (1) showed that there were highly significant differences among the two irrigation treatments and the eight maize inbreds. The interaction "treatment*inbred" was also highly significant.

The Relative water content (RWC) means for the inbred lines were ranged from 81.36 for DT190 to 43.48 for INB209 (Table 1 and figure 1). The best inbred for the relative water content (RWC) in the stressed treatment was DT190 (71.21) followed by DT62 (62.48). These cultivars were significantly different. Whereas the lowest relative water content for the stressed treatment was obtained from INB209 (43.48) and it was significantly different from INB176 (48.84). According to these results, it can be suggested that DT190, DT62 are relatively resistant to drought, but INB209 and INB176 are sensitive.

Results of Siddique et al., (2000) was in agreement with the results of this study who concluded that, exposure of plants to drought led to noticeable decreases in relative water content (RWC) with concurrent increase in leaf temperature. Results of another studies showed that, identification of resistant and sensitive genotypes was firstly based on the relative water content (RWC) measurement and showed that Triticum and Aegilops seedlings differing in their response to drought stress at the physiological and molecular levels (Rampino et al., 2006). Moreover results by Li-Ping et al. (2006) indicated that drought stress relied on drought intensity and duration, with more severe drought stress creating more serious effects on maize. Compared with well-watered conditions, during the silking and blister stages moderate stress did not significantly change the relative water content (RWC); however, severe stress significantly was decreased $(P<0.01)$ the leaf RWC.

Chen et al., (2012) evaluated maize inbred lines by selection for drought and heat stress tolerance under field conditions in 2009 and 2010 and identified several inbred lines that showed high tolerance to drought. Tolerant inbred lines (Tx205, C2A554-4, and B76) were able to maintain relatively high leaf relative water content when subjected to drought stress, while sensitive lines (B73 and $\mathrm{C} 273 \mathrm{~A}$ ) showed a rapid reduction in leaf relative water content at very early stage of drought. The tolerant lines also showed significantly greater ability to maintain vegetative growth and alleviate damage to reproductive tissues under drought conditions compared to the sensitive lines.

\section{Cell membrane thermostability}

Analysis of variance of CMT of maize genotypes under study conditions showed that there are highly significant differences among the two irrigation treatments and the eight maize inbreds. The interaction "treatment*inbred" was also highly significant. Tables 2 and figure 2 showed that plants under stressed conditions were injured more higher than well-watered plants. The highest values of cell membrane injury under Normal conditions were for INB 176 (46.67) and DT 196 (45.45). Conversely, the lowest injury resulted from plants grown in the same conditions were 29.69 and 35.00 for DT 62 and DT 235 respectively. On the other hand under stress, the highest records for cell membrane injury were 75.63 and 74.07 for inbred lines INB 209 and DT 61 respectively, while the lowest were 44.00 and 45.16 for DT 190 and DT 62 respectively (see figure 2 also).

Table1. Relative water content of maize inbred lines under normal and stressed irrigation.

\begin{tabular}{lccc}
\hline \multirow{2}{*}{ Inbread line } & \multicolumn{2}{c}{ Irrigation treatment } & \multirow{2}{*}{ Mean } \\
\cline { 2 - 4 } DT235 & Normal & Stress & 58.54 \\
DT62 & $55.13^{*}$ & 61.94 & 64.75 \\
DT190 & 67.02 & 62.48 & 76.29 \\
DT79 & 81.36 & 71.21 & 60.54 \\
DT196 & 61.60 & 59.48 & 51.54 \\
DT61 & 52.16 & 50.92 & 51.39 \\
INB176 & 52.28 & 50.49 & 51.42 \\
INB209 & 54.00 & 48.84 & 52.75 \\
Mean & 61.66 & 43.84 & 56.15 \\
\hline
\end{tabular}

L.S.D. 0.05 (Inbred Lines) $=4.69$

L.S.D. 0.05 (Irrigation Treatments) $=2.34$

L.S.D. 0.05 (Inbred Lines*Irrigation Treatments) $=6.63 *$ Mean of 5 replicates 
Table 2. Cell membrane thermostability of maize inbred lines under Normal and stressed conditions

\begin{tabular}{|c|c|c|c|c|}
\hline \multirow{2}{*}{ Inbred Lines } & \multicolumn{2}{|c|}{ Irrigation treatment } & \multicolumn{2}{|c|}{$\%$ Injury } \\
\hline & Normal & Stress & Normal & Stressed \\
\hline DT235 & $65.00^{*}$ & 50.00 & 35.00 & 50.00 \\
\hline DT62 & 70.31 & 54.84 & 29.69 & 45.16 \\
\hline DT190 & 62.96 & 56.00 & 37.04 & 44.00 \\
\hline DT79 & 60.87 & 45.00 & 39.13 & 55.00 \\
\hline DT196 & 54.55 & 34.48 & 45.45 & 65.52 \\
\hline DT61 & 57.89 & 25.93 & 42.11 & 74.07 \\
\hline INB176 & 53.33 & 27.27 & 46.67 & 72.73 \\
\hline INB209 & 56.90 & 24.37 & 43.10 & 75.63 \\
\hline
\end{tabular}

L. S. D. ${ }_{0.05}$ (Inbred Lines) $=2.53 \quad$ L. S. D. 0.05 (Irrigation Treatments) $=1.26$

L. S. D. 0.05 (Inbred Lines*Irrigation treatments) $=3.57$

${ }^{*}$ Mean of 3 replicates.

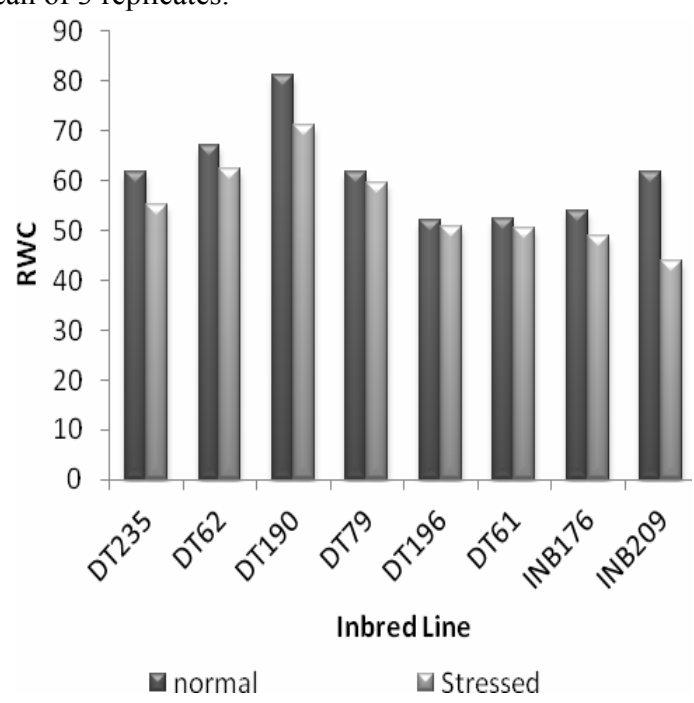

Figure1. Effect of irrigation on relative water content of eight maize inbred lines

Cell membrane thermostability was reduced because of change in secondary and tertiary structure due to higher electrolyte losses (Wahid et al., 2007), since high temperature increases kinetic energy of molecules across membranes which results in loosening of membranes either because of increase in unsaturated fatty acids or due to protein denaturation (Savchenko et al., 2002).

However, inbred lines DT 190 and DT 62 can be considered as drought tolerant these results were in accordance with Ali et al. (2011) who illustrated that a decreasing trend in CMT in maize plants in response to increasing drought levels is due to damage to membrane structure caused by drought stress, which resulted in solutes leakage from cell hence CMT was reduced. Moussa and Abdel-Aziz, (2008) Maize genotypes Giza 2 (drought tolerant) and Trihybrid 321 (drought

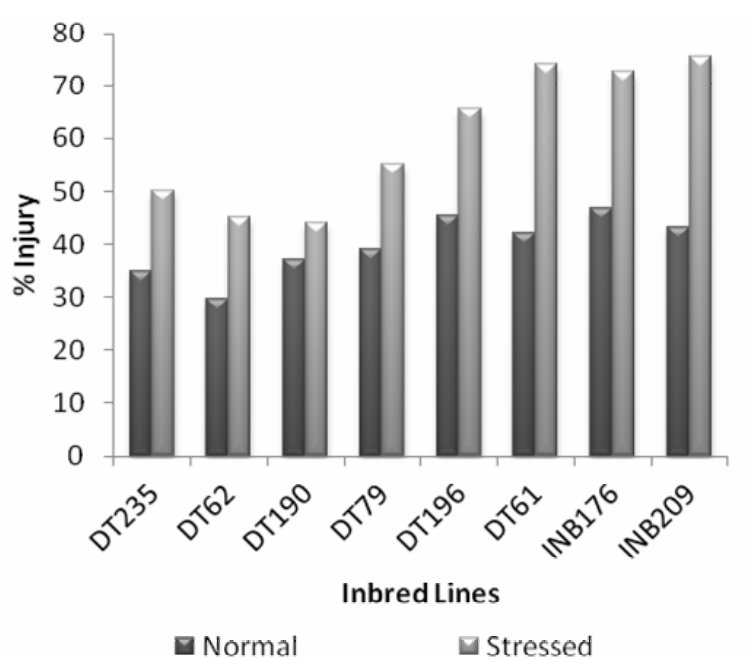

Figure 2. Effect of irrigation on cell membrane thermostability of eight maize inbred lines

sensitive) were sown in the small pots under laboratory condition. The results revealed that tolerant maize genotype; Giza 2 maintained a higher membrane stability index under water-stress conditions.

\section{Oil Content and Fatty Acids Composition}

Analysis of variance showed that water deficit and heat stressed and genotype affected both kernel oil content and fatty acids composition in different ways. It was clear that genotypes have significant effect on oleic, linoleic and arachidic acids, while water stress affected significantly on palmitic, oleic, linoleic, arachidic and homo-gamma-linolenic acids. The interaction between genotypes and water stress had a significant effect on both oleic and linoleic as shown in Tables 3 and 4. Oleic and linoleic acids concentrations were the main constituents that were affected by water 
stress. Neither genotypes nor water stress had any significant effect on stearic acid.

Table 3. Fatty acids composition of oil from eight maize inbred lines germs under normal and stressed irrigation

\begin{tabular}{|c|c|c|c|c|c|}
\hline \multirow[t]{2}{*}{ Fatty Acid } & \multirow{2}{*}{ Inbred Line (A) } & \multicolumn{2}{|c|}{ Irrigation treatment (B) } & \multirow[b]{2}{*}{ Mean (A) } & \multirow[b]{2}{*}{ L. S. D.0.05 } \\
\hline & & Normal & Stress & & \\
\hline \multirow[t]{9}{*}{ Palmitic } & DT235 & $14.17^{*}$ & 12.28 & 13.23 & $\mathrm{~A}=\mathrm{NS}$ \\
\hline & DT62 & 12.19 & 11.68 & 11.94 & $\mathrm{~B}=1.18$ \\
\hline & DT190 & 12.33 & 12.29 & 12.31 & $\mathrm{AB}=\mathrm{NS}$ \\
\hline & DT79 & 14.85 & 14.29 & 14.57 & \\
\hline & DT196 & 14.80 & 14.14 & 14.47 & \\
\hline & DT61 & 15.03 & 12.80 & 13.92 & \\
\hline & INB176 & 13.83 & 11.52 & 12.68 & \\
\hline & INB209 & 13.62 & 10.71 & 12.17 & \\
\hline & Mean (B) & 13.85 & 12.46 & & \\
\hline \multirow[t]{9}{*}{ Stearic } & DT235 & 3.74 & 3.56 & 3.65 & $\mathrm{~A}=\mathrm{NS}$ \\
\hline & DT62 & 4.66 & 4.15 & 4.41 & $\mathrm{~B}=\mathrm{NS}$ \\
\hline & DT190 & 5.22 & 3.62 & 4.42 & $\mathrm{AB}=\mathrm{NS}$ \\
\hline & DT79 & 3.50 & 3.10 & 3.30 & \\
\hline & DT196 & 5.45 & 4.37 & 4.91 & \\
\hline & DT61 & 5.39 & 4.73 & 5.06 & \\
\hline & INB176 & 7.36 & 5.85 & 6.61 & \\
\hline & INB209 & 6.11 & 5.14 & 5.63 & \\
\hline & Mean (B) & 5.18 & 4.32 & & \\
\hline \multirow[t]{9}{*}{ Oleic } & DT235 & 24.00 & 35.85 & 29.93 & $\mathrm{~A}=2.36$ \\
\hline & DT62 & 25.35 & 38.32 & 31.84 & $\mathrm{~B}=1.18$ \\
\hline & DT190 & 27.11 & 35.17 & 31.14 & $\mathrm{AB}=3.33$ \\
\hline & DT79 & 17.70 & 18.59 & 18.15 & \\
\hline & DT196 & 24.99 & 28.28 & 26.64 & \\
\hline & DT61 & 25.67 & 32.30 & 28.99 & \\
\hline & INB176 & 28.98 & 38.24 & 33.61 & \\
\hline & INB209 & 22.47 & 35.78 & 29.13 & \\
\hline & Mean & 24.53 & 32.82 & & \\
\hline \multirow[t]{9}{*}{ Linoleic } & DT235 & 36.49 & 30.83 & 33.66 & $\mathrm{~A}=2.36$ \\
\hline & DT62 & 50.58 & 45.97 & 48.28 & $\mathrm{~B}=1.18$ \\
\hline & DT190 & 34.80 & 31.74 & 33.27 & $\mathrm{AB}=3.33$ \\
\hline & DT79 & 30.07 & 31.68 & 30.88 & \\
\hline & DT196 & 35.59 & 34.16 & 34.88 & \\
\hline & DT61 & 30.84 & 25.48 & 28.16 & \\
\hline & INB176 & 33.09 & 31.00 & 32.05 & \\
\hline & INB209 & 35.22 & 29.38 & 32.30 & \\
\hline & Mean (B) & 35.84 & 32.53 & & \\
\hline \multirow[t]{9}{*}{ Arachidic } & DT235 & 0.61 & 0.47 & 0.54 & $\mathrm{~A}=0.12$ \\
\hline & DT62 & 0.35 & 0.35 & 0.35 & $\mathrm{~B}=0.06$ \\
\hline & DT190 & 0.32 & 0.21 & 0.27 & $\mathrm{AB}=\mathrm{NS}$ \\
\hline & DT79 & 0.34 & 0.27 & 0.31 & \\
\hline & DT196 & 0.48 & 0.30 & 0.39 & \\
\hline & DT61 & 0.42 & 0.31 & 0.37 & \\
\hline & INB176 & 0.42 & 0.21 & 0.32 & \\
\hline & INB209 & 0.43 & 0.25 & 0.34 & \\
\hline & Mean (B) & 0.42 & 0.30 & & \\
\hline Homo- & DT235 & 0.22 & 0.13 & 0.18 & $\mathrm{~A}=\mathrm{NS}$ \\
\hline Gamma- & DT62 & 0.37 & 0.13 & 0.25 & $\mathrm{~B}=0.06$ \\
\hline \multirow[t]{6}{*}{ Linolenic } & DT190 & 0.18 & 0.12 & 0.15 & $\mathrm{AB}=\mathrm{NS}$ \\
\hline & DT79 & 0.18 & 0.12 & 0.15 & \\
\hline & DT196 & 0.17 & 0.15 & 0.16 & \\
\hline & DT61 & 0.14 & 0.12 & 0.13 & \\
\hline & INB176 & 0.17 & 0.16 & 0.17 & \\
\hline & INB209 & 0.14 & 0.11 & 0.13 & \\
\hline
\end{tabular}




\begin{tabular}{|c|c|c|c|c|c|c|}
\hline \multicolumn{3}{|c|}{$\%$} & \multicolumn{2}{|r|}{0.13} & & \\
\hline \multicolumn{6}{|c|}{$\begin{array}{l}\text { Mean of } 3 \text { replicates } \mathrm{NS}=\text { Differences are not significant at } p=0.05 \\
\text { Table 4. Fat content percentage, usaturated fatty acids/saturated fatty acids ratio, } \\
\text { oleic/stearic ratio and linoleic/oleic ratio of eight maize inbred lines under normal and } \\
\text { stressed irrigation }\end{array}$} & \\
\hline Inbred I & & $\%$ Fat content & $\%$ Fat content reduction & UFA:SFA & Oleic:Stearic & Linoleic:Oleic \\
\hline \multirow{2}{*}{ DT235 } & $\mathrm{N}$ & 1.51 & 50.99 & 3.28 & 6.42 & 1.52 \\
\hline & $\mathrm{S}$ & 0.74 & & 4.10 & 10.07 & 0.86 \\
\hline \multirow{2}{*}{ DT62 } & $\mathrm{N}$ & 1.02 & 6.86 & 4.44 & 5.44 & 2.00 \\
\hline & $\mathrm{S}$ & 0.95 & & 5.22 & 9.23 & 1.20 \\
\hline \multirow{2}{*}{ DT190 } & $\mathrm{N}$ & 1.12 & 52.68 & 3.47 & 5.19 & 1.28 \\
\hline & $\mathrm{S}$ & 0.53 & & 4.16 & 9.72 & 0.90 \\
\hline \multirow{2}{*}{ DT79 } & $\mathrm{N}$ & 0.81 & 8.64 & 2.57 & 5.06 & 1.70 \\
\hline & $\mathrm{S}$ & 0.74 & & 2.85 & 6.00 & 1.70 \\
\hline \multirow{2}{*}{ DT196 } & $\mathrm{N}$ & 0.77 & 31.17 & 2.93 & 4.59 & 1.42 \\
\hline & $\mathrm{S}$ & 0.53 & & 3.33 & 6.47 & 1.21 \\
\hline \multirow{2}{*}{ DT61 } & $\mathrm{N}$ & 0.77 & 12.99 & 2.72 & 4.76 & 1.20 \\
\hline & $\mathrm{S}$ & 0.67 & & 3.25 & 6.83 & 0.79 \\
\hline \multirow{2}{*}{ INB176 } & $\mathrm{N}$ & 0.74 & 9.46 & 2.88 & 3.94 & 1.14 \\
\hline & $\mathrm{S}$ & 0.67 & & 3.95 & 6.54 & 0.81 \\
\hline \multirow{2}{*}{ INB209 } & $\mathrm{N}$ & 0.95 & 22.11 & 2.87 & 3.68 & 1.57 \\
\hline & $\mathrm{S}$ & 0.74 & & 4.05 & 6.96 & 0.82 \\
\hline
\end{tabular}

As shown in Table 4, the total oil content in all genotypes subjected to water constraint declined significantly $(\mathrm{P}<0.05)$ as compared to control plants. The lowest genotype in oil content loss was DT62 $(6.86 \%)$ while DT190 was the most genotype which lost its oil content by about $52.68 \%$. Drought stress significantly reduced the seed oil content of two maize cultivars, however, the more drought induced reduction in seed oil contents was observed in cv.Agaiti-2002 (drought tolerant) though this cultivar had higher seed oil content under non-stress conditions, (Ali et al., 2009).In addition, Zhong et al., (2011) and Orhun and Korkut, (2011) observed a direct relationship between oil content and unsaturated fatty acids (oleic, linoleic and linolenic) in Bermuda grass and maize, but saturated fatty acids (palmitic, stearic) have showed non-significant correlations with oil content.

There is also an increasing in both ratios of unsaturated/saturated fatty acids (average increased from 3.15 to 3.86) and oleic/Stearic (average increased from 4.89 to 7.73 ) revealed that unsaturation of fatty acids increased under drought stress (table 5). These results are similar to those obtained in a previous work by Flagella at al. (2002) and Ali et al. (2010) and who showed that contents of oleic acid in the maize kernel oil increased due to water stress with a subsequent decrease in linoleic acid caused an increased oleic/linoleic ratio of kernel oil from drought stressed plants. Also these results are in agreement with those obtained by Bellaloui et al. (2013) who indicated that both water stress and high temperature altered seed oil composition of soybean by increasing oleic acid and decreasing linoleic and linolenic acid concentrations. Severe water stress or high temperature resulted in higher palmitic acid and lower stearic acid.

\section{CONCLUSION}

From the previous results, it can be concluded that drought and heat might be considered as the most visible factors which affected the physiology and oil composition of maize. Oil content, degree of unsaturation and fatty acid composition are the most affected parameters by water deficit and heat. Maize genotypes were differed in their response to drought and heat. DT62 and DT190 from the eight studied genotypes are the less oil composition affected under drought and heat stress and it's recommended to be used in the improvement breeding programmers in Egypt.

\section{REFERENCES}

Ali, Q., Ashraf, M., \& Anwar, F. (2009). Physico-chemical attributes of seed oil from drought stressed sunflower (Helianthus annuus L.) plants. Grasas Y Aceites, 60(5), 477-483.

Ali, Z., Basra, S. M. A., Munir, H., Mahmood, A., \& Yousaf, S. (2011). Mitigation of drought stress in maize by natural and synthetic growth promoters. Journal of Agriculture and Social Sciences (Pakistan).

Becker, R. (2007). Fatty acids in food cereal grains and grain products. Fatty Acids in Foods and their Health Implications, 303-316. 
Bellaloui, N., \& Mengistu, A. (2008). Seed composition is influenced by irrigation regimes and cultivar differences in soybean. Irrigation Science, 26(3), 261-268.

Bellaloui, N., Mengistu, A., \& Kassem, M. A. (2013). Effects of genetics and environment on fatty acid stability in soybean seed.

Chen, J., Xu, W., Velten, J., Xin, Z., \& Stout, J. (2012). Characterization of maize inbred lines for drought and heat tolerance. Journal of Soil and Water Conservation, 67(5), 354-364.

Cornic, G. (2000). Drought stress inhibits photosynthesis by decreasing stomatal aperture-not by affecting ATP synthesis. Trends in plant science, 5(5), 187-188.

Cui, L., Li, J., Fan, Y., Xu, S., \& Zhang, Z. (2006). High temperature effects on photosynthesis, PSII functionality and antioxidant activity of two Festuca arundinacea cultivars with different heat susceptibility. Stud, 47, 61-69.

Flagella, Z., Rotunno, T., Tarantino, E., Di Caterina, R., \& De Caro, A. (2002). Changes in seed yield and oil fatty acid composition of high oleic sunflower (Helianthus annuus L.) hybrids in relation to the sowing date and the water regime. European journal of agronomy, 17(3), 221-230.

Folch J, L. M., Stanley GHS (1957). "A simple method for the isolation and purification of total lipids from animal tissues." Journal of Biol Chem 226:297-509.

Gomathi, R., \& Rakkiyapan, P. (2011). Comparative lipid peroxidation, leaf membrane thermostability, and antioxidant system in four sugarcane genotypes differing in salt tolerance. Int. J. Plant Physiol. Biochem, 3(4), 6774.

González, L., \& González-Vilar, M. (2001). Determination of relative water content. Handbook of plant ecophysiology techniques, 207-212.

Ibrahim, A. M., \& Quick, J. S. (2001). Genetic control of high temperature tolerance in wheat as measured by membrane thermal stability. Crop science, 41(5), 1405-1407.

Jamal, A., Shahid, M. N., Aftab, B., Rashid, B., Sarwar, M. B., Mohamed, B. B., ... \& Husnain, T. (2014). Water Stress Mediated Changes in Morphology and Physiology of Gossypium arboreum (Var FDH-786). Journal of Plant Sciences, 2(5), 179-186.

Jiang, Y., \& Huang, B. (2001). Drought and heat stress injury to two cool-season turfgrasses in relation to antioxidant metabolism and lipid peroxidation. Crop Science, 41(2), 436-442.

Kebede, H., Abbas, H. K., Fisher, D. K., \& Bellaloui, N. (2012). Relationship between aflatoxin contamination and physiological responses of corn plants under drought and heat stress. Toxins, 4(11), 1385-1403.

Li-Ping, B. A. I., Fang-Gong, S. U. I., Ti-Da, G. E., Zhao-Hui, S. U. N., Yin-Yan, L. U., \& Guang-Sheng, Z. H. O. U. (2006). Effect of soil drought stress on leaf water status, membrane permeability and enzymatic antioxidant system of maize. Pedosphere, 16(3), 326-332.

Merah, O. (2001). Potential importance of water status traits for durum wheat improvement under Mediterranean conditions. The Journal of Agricultural Science, 137(02), 139-145.

Moussa, H. R., \& Abdel-Aziz, S. M. (2008). Comparative response of drought tolerant and drought sensitive maize genotypes to water stress. Aust J Crop Sci, 1(1), 31-36.

Nagarajan, S., \& Nagarajan, S. (2010). Abiotic tolerance and crop improvement. Abiotic Stress Adaptation in Plants, 111.

Orhun, G. E., \& Korkut, K. Z. (2011). Interrelationships among the oil and fatty acids in maize. African Journal of Agricultural Research, 6(9), 2115-2117.

Rampino, P., Pataleo, S., Gerardi, C., Mita, G., \& Perrotta, C. (2006). Drought stress response in wheat: physiological and molecular analysis of resistant and sensitive genotypes. Plant, cell \& environment, 29(12), 2143-2152.

Ritchie, S. W., Nguyen, H. T., \& Holaday, A. S. (1990). Leaf water content and gas-exchange parameters of two wheat genotypes differing in drought resistance. Crop science, 30(1), 105-111.

Rizhsky, L., Liang, H., Shuman, J., Shulaev, V., Davletova, S., \& Mittler, R. (2004). When defense pathways collide. The response of Arabidopsis to a combination of drought and heat stress. Plant physiology, 134(4), 1683-1696.

Savchenko, G. E., Klyuchareva, E. A., Abramchik, L. M., \& Serdyuchenko, E. V. (2002). Effect of periodic heat shock on the inner membrane system of etioplasts. Russian journal of plant physiology, 49(3), 349-359.

Siddique, M. R. B., Hamid, A., \& Islam, M. S. (2000). Drought stress effects on water relations of wheat. Botanical Bulletin of Academia Sinica, 41.

Triboi, E., \& Triboi-Blondel, A. M. (2002). Productivity and grain or seed composition: a new approach to an old problem-invited paper. European Journal of Agronomy, 16(3), 163-186.

Tripathy, J. N., Zhang, J., Robin, S., Nguyen, T. T., \& Nguyen, H. T. (2000). QTLs for cell-membrane stability mapped in rice (Oryza sativa L.) under drought stress. Theoretical and Applied Genetics, 100(8), 1197-1202.

Wahid, A., Gelani, S., Ashraf, M., \& Foolad, M. R. (2007). Heat tolerance in plants: an overview. Environmental and Experimental Botany, 61(3), 199-223.

Watson, S. A., White, P. J., \& Johnson, L. A. (2003). Description, development, structure, and composition of the corn kernel. Corn: chemistry and technology, (Ed. 2), 69-106.

White, P. J., Weber, E. J., \& Johnson, L. A. (2003). Lipids of the kernel. Corn: Chemistry and technology, (Ed. 2), 355405.

Zhang, M., Kang, M. S., Reese Jr, P. F., \& Bhardwaj, H. L. (2006). Soybean cultivar evaluation via GGE biplot analysis. Journal of New Seeds, 7(4), 37-50.

Zhong, D., Du, H., Wang, Z., \& Huang, B. (2011). Genotypic variation in fatty acid composition and unsaturation levels in bermudagrass associated with leaf dehydration tolerance. Journal of the American Society for Horticultural Science, 136(1), 35-40. 



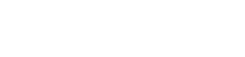 \\ محتوى الزبت وتركيب الأحملن الدهنية لحبوب الذرة تحت تأثير الحرارة ولاجهاد المائي}

أشجان أبو جلل، أميرة زيتون الفئن

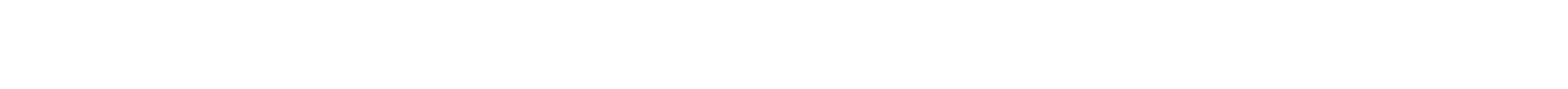

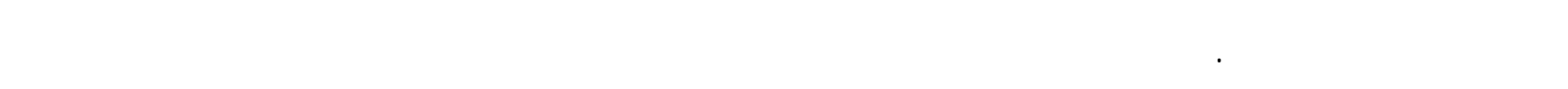

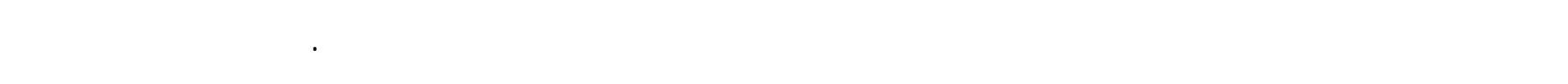

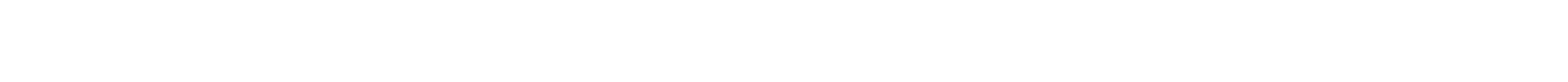

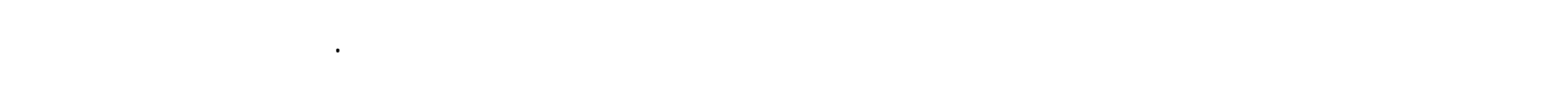

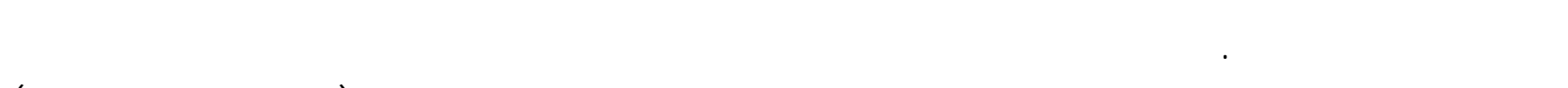

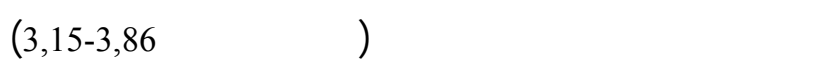

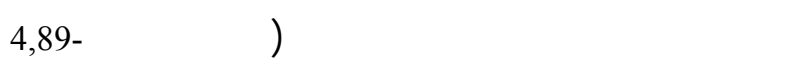

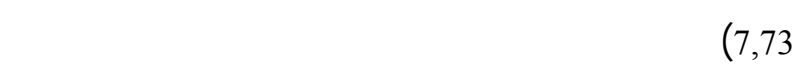
تهت تأثير كلا الضطين. وقد أشارت النتائج أن النطين النماضين

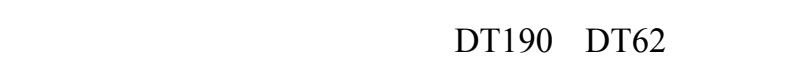

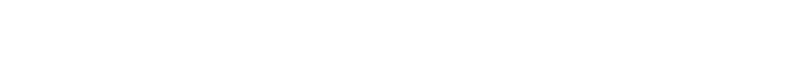

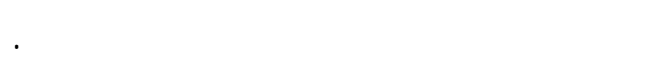

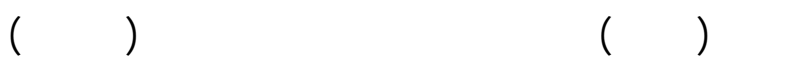

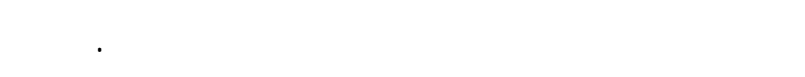

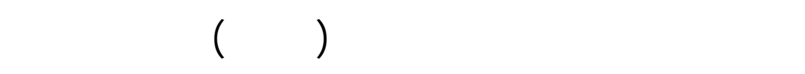

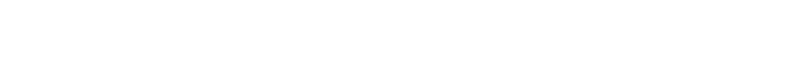

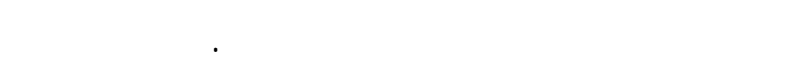

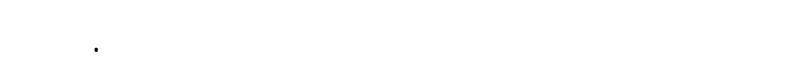
واضحا أن للأنملط الجينية تأثيركبير النهب على لحماض الأوليك 